\title{
Individual Differences Versus Consumer Readiness Variables Predictive Power Over Internet Banking Adoption in South Africa
}

\author{
Aguidissou O. C., Richard Shambare, Rugimbana R \\ Business School, Tshwane University of Technology, South Africa \\ Omerich@yahoo.fr, rshambare@gmail.com, RugimbanaR@tut.ac.za
}

\begin{abstract}
Self-service banking technology is gaining recognition globally in spite of its numerous challenges. Debit cards, ATMs and other Self Service Technologies (SSTs) are well received in South African market; however, customers seem cynical about Internet Banking (IB). IB consumer's adoption patterns frameworks are tested within this paper based on a framework providing for the South African market with the best explanatory power. Thus, investigating consumer readiness (CR) and individual differences (IDs) variables as common groupings usually cited in the literature consumer variables predictive efficacy, provide better understanding of the consumers towards SSTs in South Africa.CR comprises role clarity, ability and motivation (extrinsic and intrinsic), while IDs includes inertia, technology anxiety, need of interaction, previous experience and demographics. This study purposes to identify among IDs and CR variables, which one with greater predictive power on IB adoption in South Africa.Considering this gap within the body of knowledge, in relation with IB adoption behaviour among the South African consumer is therefore the present article primary objective. Consumer's individual differences (technology anxiety and education variables specifically) as exogenous variables, through a large sample size $(n=1516)$, descriptive quantitative analysis, were found in context of South African market with greatest predictive power for IB adoption by comparison over consumer readiness. In South Africa particularly for marketers, these findings therefore are a set of relevant keys that can be useful in promoting IB adoption.
\end{abstract}

\section{Keywords: Internet banking, Consumer choice behaviour, Individual differences, Consumer readiness}

\section{Introduction}

The banking industry in South Africa has experienced meaningful reforms in the past recent decades. In the 1990s South Africa went through progressive financial service deregulation and this has largely shaped the country retail banking (Falkena, Bamber, Llewellin \& Store, 2001; Moyo, Nandwa, Oduor \& Simpasa, 2014:24). As result of the global deregulation trend, various self-imposed monopolies and restrictions were removed in South African banking industry. For instance financial institutions were now permitted to offer banking services, and by so doing increase the industry competitive pressure. Banking institutions were specialised in innovations products as electronic banking systems and channels of technologies-based products as strategies to maintain rapid distribution and diffusion (Falkena, Bamber, Llewellin \& Store, 2001, 2001:390; Moyo, Nandwa, Oduor \& Simpasa, 2014:2-4). A range of SST services were introduced between 1996 and 2000 (Manson, 2002) these include debit cards, ATMs among others. These became the main SST and were well received in South African market; however, customers were undecided about IB usage (Maduku, 2013:78). IB, within the retail banking in South African market still occupied the lowest rank as adopted SST (World Wide Worx, 2013) and for IB consumer patronage, subsequent encouraging efforts were used. Formulating effective marketing strategies policies' challenges remained within financial institutions while seeking to increase IB usage (Wu, 2005; Maduku, 2013:94; Agwu, 2015:100). Internet and Internet banking diffusion knowledge and patterns of adoption are limited. In spite of IB international increasingly recognition, South African decision makers still lack appropriated sound policy as far as the marketing is concerned. Academic research regarding IB adoption area in South Africa and remaining others developing countries in the world remained scanty (Ramavhona \& Mokwena, 2016:2) and in most cases inconclusive as focusing only on one common grouping variables. Sound scientific guidance work is therefore needed for the shifting of consumer behaviour to IB adoption. Considering this gap within the body of knowledge, in relation with IB adoption behaviour among the South African consumer is therefore the present article primary objective as far as clarification among findings inconsistencies' is concerned. This paper, against this background seeks to test different IB consumer adoption patterns' conceptual frameworks intents to ascertain for the South African market, the framework with best explanatory power. Following section is on discussion regarding IB in South Africa. Then a presentation of IB adoption framework is made. The 
methodology further with findings section is presented. Results and discussion regarding summary findings, managerial, limitation and recommendation on future research will close the section.

\section{Literature Review}

Internet banking in South Africa:The South Africa's return into the universal economy since the early 1990s, the deregulation's global trend, the universal's financial services conglomerates rising and the accelerated technological expansions all together contributed to the new shaping of the financial sector in South Africa (Falkena et al., 2001:80; Baliamourne, 2002). Today e-banking services are provided by the totality of South African banks like the 'big four' namely ABSA, FNB, Standard Bank and Nedbank (Ramavhona \& Mokwena, 2016:2). With only 23 per cent, the South Africa's IB user rate is still notably low (World Wide Worx, 2013). IB is customers' banking services delivery using the Internet network (Yiu, Grant \& Edgar, 2007:337; Ramavhona \& Mokwena, 2016:2). Balances checking, third-party payment and inter accounttransfers are various functions available while using IB, as it is for e-banking (Kyobutungi, 2014). Subsequently, online banking functions are performed within this process by the consumer (Onay \& Ozsaz, 2013).Very few works has been done in South Africa in order to reinforce banking SSTs marketers' knowledge regarding consumer's attitudes to their adoption (or rejection). Thus, conducting further research on IB is therefore crucial to the advancement of IB in South Africa. Through this research, new contributions will be made in the area of consumer's perception of IB usage, adoption of IB and consumer behaviour. To achieve the stated objective, the study developed a framework for individual differences and consumer readiness, predictive power over internet banking adoption in South Africa.

Internet banking adoption framework: Meuter et al. (2005:63) identify the five individual characteristics that influence the usage of technologies, as: inertia, technology anxiety, needs for interaction, previous experience and demographics. Research findings demonstrate that these factors also influence technology innovation adoption (Kelly, Lawlor \& Mulvey, 2010:1). These factors are accepted in this research framework model to test their predictive power on IB adoption in the South African context, as it is in Meuter et al. (2005:63), as they are not easily manipulated (age, sex) or easily managed (complexity and trialability) before the self-service technology (SST) is introduced. While the antecedent theories proved the relevance of perceived notions in the adoption process, these theories argue that adoption drivers look more complicated than just a notion of perceptions. Along this line of thought, factors such as individuals' propensity to accept new technologies, and their motivation and possession of skills to use specific technologies, are responsible for adoption (Parasuraman, 2000; Meuter et al., 2005; Seligman, 2006). This article focuses on IB as SST adoption case, which provides understanding on attitudes, consumer readiness or behaviours that are used. The "state in which consumers are prepared and likely to use an innovation for the first time" is defined as CR (Meuteret al., 2005:64). As evidence, CR is a key component of the present study framework. "There are certain innovation characteristics or individual differences that vary in direction and significance across different contexts" (Meuter et al., 2005:62). In order to explain links among variables, and inconsistencies' clarifications therefore using of mediating variables is suggested. As consumer's adoption first step, consumer readiness variable is in place to mediate between the behaviour of trial (of the innovation) and individual differences variables. This paper on model of Meuter et al. (2005) is therefore on individual differences and consumer readiness predictive power identification. The individual differences variables are first of all defined or characterized followed by consumer readiness.

Inertia: Inertia can be explained as a state where people are found reluctant to change (Kuppens, Allen \& Sheeber, 2010:984).

Technology anxiety: Technology anxiety is described as a "modern disease of adaptation caused by an inability to cope with new computer technologies in a healthy manner" (Fiehn, 2010:255).

Need for interaction: Need for personal interaction, may decrease the desire to try a new technology product or service, by so doing becoming a motivation inhibitor factor that lowers interest in learning a SSTs function mode (Meuter et al., 2005:66).

Previous experience: People with an e-mail account and experience in using Internet are more positively disposed to try Internet banking than those without any previous experience.

Demographic characteristics: Demography in general focuses on human population statistics, including size, age, gender, race, location, occupation, income, education and other characteristics (Wu, 2005). 
Age: People who adopt Internet banking are mostly younger one (Clemes, Gan \& Du, 2012).

Education level: "Higher education may lead to confidence (ability) and the perception of the SST as more understandable (role clarity) and rewarding (motivation)" (Meuter et al., 2005:64).

Gender: Female respondents are more likely to adopt Internet banking than males in Nigeria (Gao \& Owolabi, 2008:299).

Income: "Higher income may increase the chances of access to the required tools (ability) and the motivation (time savings, or other) to use SSTs.

Consumer readiness encompasses role clarity, motivation (as well as intrinsic than extrinsic) and ability. The readiness of a customer to use a product is an expression of his behaviour regarding it. Someone that is not knowledgeable, without motivation or lack skill on using IB may never become a technological banking innovations potential user. "Readiness" is delineated as the willingness, preparedness and ability state to engage in IB adoption. Consumer readiness variables are found in Meuter et al. (2005:76) case with more powerful predictability compare to others variables regarding SSTs consumer's adoption.Role clarity refers to knowledge and understanding of customers regarding the nature of contribution needed to take place. In fact for customers, knowing what to do and to expect as performance greatly influences on doing things to do.

Motivation: Motivation has the "forerunner of any tangible achievement in life" (Adeboye, 2015). Linking identity to motivation, "identity-based motivation results in the readiness to take action, even when the action is not beneficial to the participant or is unlikely to have been chosen outside of the specific context" (Oyserman \& Sorrenson, 2009:253)

Ability: Ability is about the magnitude to which consumer has the required skills and empowerment to run a particular duty or in case of new innovation using (Meuter et al., 2005:64).

Figure 1: Proposed Conceptual Model

Antecedents Predictors Mediating Variables

Adoption Process

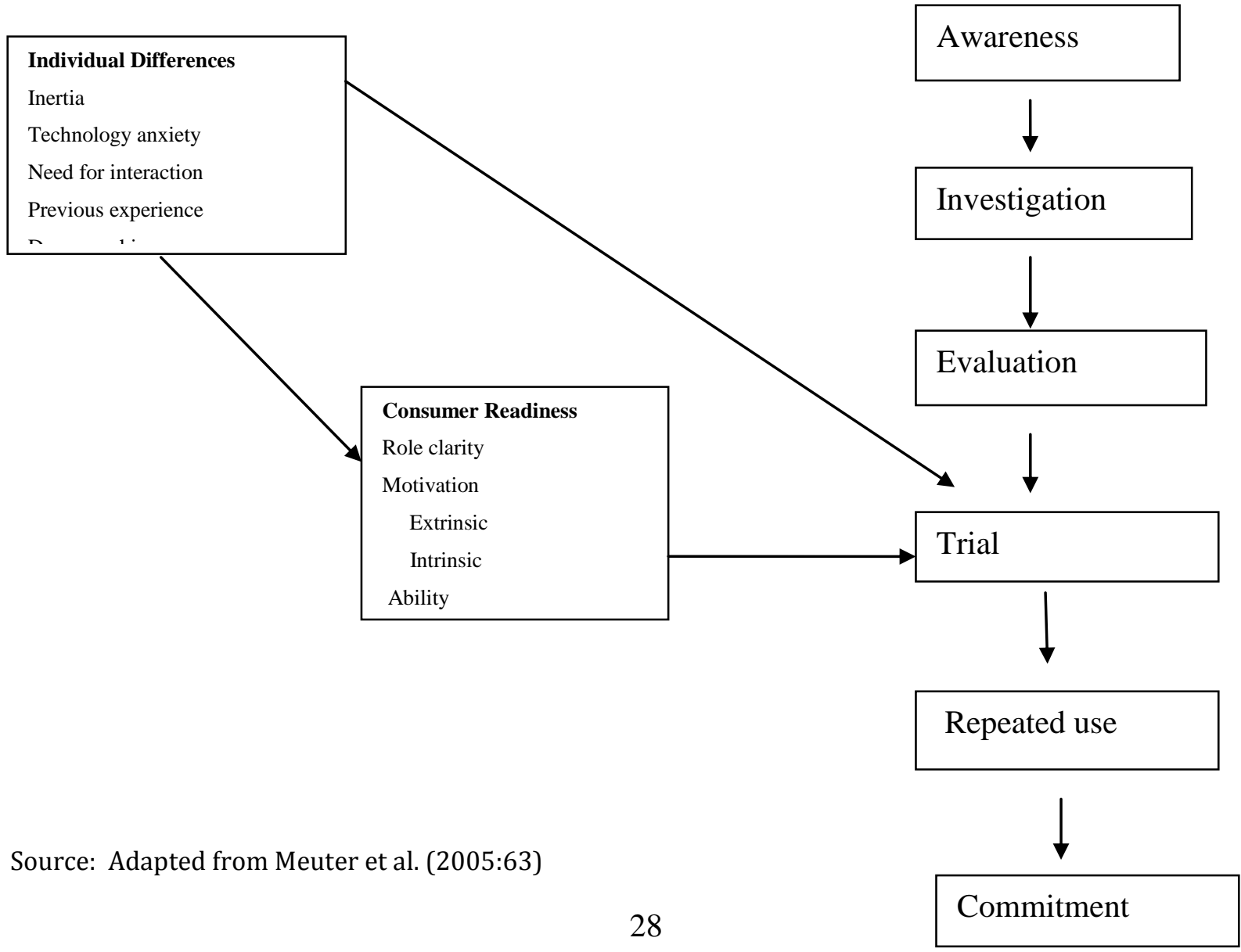


Conclusively, individual differences and consumer readiness variables are the two set of variables mixed with the intent for results which are accurate and credible.

Research questions and hypotheses: The following research question was formulated: In South Africa, what is the predictive power of exogenous and endogenous variables on Internet banking adoption among consumers?

Consequently the research hypotheses are formulated as follows and offered basis for data collection and data analysis:

$\mathrm{H}_{1}$ : Role clarity mediates the relationship between:

Individual differences variables and trial

$\mathrm{H}_{2}$ : Extrinsic motivation mediates the relationship between:

Individual differences variables and trial

$\mathrm{H}_{3}$ : Intrinsic motivation mediates the relationship between:

Individual differences variables and trial

$\mathrm{H}_{4}$ : Ability mediates the relationship between:

Individual differences variables and trial

$\mathrm{H}_{5}$ : The consumer readiness variables are better predictors of trial than:

Individual differences variables

\section{Methodology}

The methodology used in this paper is descriptive single cross-sectional design (Malhotra, 2010:108). Data collection was based on structured questionnaire. Data were analyzed using frequency table, bivariate and multivariate analysis. A descriptive single cross-sectional design according to Malhotra (2010:108) is the applied methodology for this study. From self-completion structured questionnaire respondents, data was collected. For data analysis, the analysis of statistics was made in line with the collected quantitative data.

Sample: The empirical inquiry quantitative method, employing the survey research design which is descriptive one, and was used for investigation related to the present study (Malhotra, 2010:108). Through self-completion structured questionnaires, data was collected from respondents with a 'drop and pick' technique collection method. The theory in this research is tested and existed one, and "explains the precise relationships between variables" (Perry, 2002:26). Therefore, in design, this research in nature is explanatory, causal one ( $\mathrm{Nel}, 2013: 78-79$ ). With a large sample size 1516, surpassing 590 as minimum recommended (Pallant, 2010) and 385(Raosoft, 2016), study findings are sufficiently generalisable. For a selected sample in line with the Gauteng province population characteristics, a technique of stratified sampling was employed. Based on Healy and Perry (2000:120) view the constructs to be measured and the influencing choice behaviour factors are known as 'real-life' phenomena which were identified and tested in past research (Berndt, Saunders \& Petzer, 2010; Black, Lockett, Winklhofer \& Ennew 2001; Laukkanen, Sinkkonen, Kivijarvi \& Laukkanen, 2007; Parasuraman, 2000; Rugimbana, 1998; Shambare, 2012). Quantitative methods approach was employed in the vast majority of IB studies as long as measuring adoption is concerned. But in case of some studies, only qualitative approach had been utilized (Szmigin \& Bourne, 1999; Black et al., 2001; Mallat, 2007; Agwu, 2014). This gives reason of quantitative techniques used in this study. The population for this study consists first of all of all adult persons in the Gauteng Province of South Africa, of roughly 7000000 (StatsSA, 2014). With such population, sample size of between 200 and 1000 respondents would probably be considered by most researchers (Sathye, 1999). Sample size calculator the minimum expected as sample size is 385 (Raosoft, 2016). A large sample of 1516 questionnaires respondents students fully completed, was used during the present study for a total of 2150 distributed for the investigation with 634 unused for duplication and irrelevant data. Using a homogenous sample was preferable (i.e., students, known as homogeneous sample) and using homogenous samples, is desirable for theory testing (Calder et al., 1981:200).

Questionnaire adaptation: Questionnaire was used as the instrument for measuring diverse aspects in relation to respondents' demographic characteristics, banking profiles and the related parameters. 
Table 1: Data collection instrument format

\begin{tabular}{|c|c|c|c|}
\hline Section & Section summary & Scale development & Rationale \\
\hline \multirow[t]{3}{*}{$A$} & $\begin{array}{l}\text { Respondents' banking profile: } \\
\text { Information in the banking profile area. } \\
\text { This encompasses the types of bank } \\
\text { accounts utilised and also how often these } \\
\text { were utilised. }\end{array}$ & $\begin{array}{l}\text { Brown, Cajee, Davies } \\
\text { and Stroebel (2003); } \\
\text { Rugimbana (1998) }\end{array}$ & $\begin{array}{lr}\begin{array}{l}\text { To } \\
\text { respondents' } \\
\text { patterns }\end{array} & \text { banking } \\
\end{array}$ \\
\hline & $\begin{array}{l}\text { Antecedent predictors' scales: } \\
\text { Measure independent and mediating } \\
\text { variables. }\end{array}$ & $\begin{array}{l}\text { Meuter et al. (2005); } \\
\text { Parasuraman (2000); }\end{array}$ & Measuring TR and CR \\
\hline & $\begin{array}{ll}\text { Respondents' } & \text { demographic } \\
\text { characteristics: } & \\
\text { Demographics } & \end{array}$ & $\begin{array}{l}\text { Developed for this } \\
\text { research from the } \\
\text { literature review }\end{array}$ & $\begin{array}{l}\text { To describe } \\
\text { demographic } \\
\text { characteristics of the } \\
\text { sample }\end{array}$ \\
\hline
\end{tabular}

Source: Researcher's own construct

The primary objective of this study is to test the predictive power of antecedent predictor variables (individual differences) and mediating predictor variables namely consumer readiness variables, in order to predict consumer choice behavior. Three relevant elements are underlined in area of the proposed conceptual framework in relation with IB choice: Operationalised by trial, Individual differences, consumer readiness and adoption represent those parameters. A structured questionnaires and a Likert scale $(1=$ Strongly Disagree; $5=$ Strongly Agree) were used. The first two are continuous variables and by using a 5 point Likert scale anchored at $1=$ Strongly Disagree and $5=$ Strongly Agree, were measured. Adoption is a nominal discrete value as measured by trial. In total, the respondents' banking profile, measurement scales and demographic sections are the questionnaire three parts, eight pages long (Table 1). For 2150 questionnaires respondents collected, 1516 responses were utilized for the present research conducted, as survey total sample size with $54,20 \%$ as female and $45,80 \%$ as male; with $93.70 \%$ as undergraduate, $69,90 \%$ of these students age is between $21-30$ years with $93.70 \%$ as undergraduate. Among participants 78 , $70 \%$ are with monthly income not more than 5000 (ZAR) and $62,10 \%$ as full time students. Participant demographic characteristic is illustrated in Table 2 below. Various statistical analyses performed by using SPSS v. 23 (Field, 2009; Ramavhona \& Mokwena, 2016:4).

Data analysis: Various statistical analyses were conducted based on the result of the collected quantitative data. SPSS v. 23 in order to run analyses as followed were used (Field, 2009).

Descriptive statistics - for samples' demography and their banking profiles description (Daniel \& Terrel, 1995:42).

Chi-square tests: to identify associations between variables (Field, 2009:269).

Reliability analysis: Cronbach's alpha is used for assessing measurement scales' internal consistency (reliability) (Emory \& Cooper, 1991:187).

Factor analysis: For variables reducing into latent variables' smaller groups, including validity's tests (Field, 2009:629; Malhotra \& Birks, 2007:125).

Multiple regression and logistic regression: for the model proposed and hypotheses testing (Hair, Black, Babin, Anderson \& Tatham, 1998:90)

\section{Results}

Out of 2150 questionnaires distributed to the respondents, $1516(70.51 \%)$ collected and the responses were used for the present study. The male respondent participant rate of $45.8 \%$ was smaller than their female counterparts which is $54.20 \%$ as described on Table 2. Significantly, the proportion of $69.9 \%$ is representative of the age group 21 to 30 years. $21.80 \%$ and $8.30 \%$ represent respectively respondent age group for less than 20 years and more than 30 years according to present investigation.Table 2, depicted also that the biggest percentage (78.7\%) of participants are undergraduate with an income of not more than R5 000 per month, while the remaining of $6.30 \%$ are postgraduate. As presented by Table 2, only $7.10 \%$ of respondent earn more than R15 000 per month, while $11.30 \%$ monthly earning, is not more than R10 000 . 


\section{Journal of Economics and Behavioral Studies (ISSN: 2220-6140)}

Vol. 9, No. 6, pp. 26-38, December 2017

The fewest 2.90\% respondent monthly earning is between R10 001 and R15 000. Full time student with $62.10 \%$ constitutes the highest rate of this present research participant, while the lowest rate of $2.70 \%$ refers to self-employed student participant. The remaining, $6.50 \%, 5.30 \%, 12.90 \%$ and $10.50 \%$ are respectively fulltime employed students, part-time employed students, part-time students and unemployed or retired as shown in Table 2. This provides the key demographic characteristics of the study sample.

Table 2: Demographic profile

\begin{tabular}{lll}
\hline Demographic characteristic & South Africa (\%) \\
\hline Gender & Male & 45.80 \\
& Female & 54.20 \\
& & \\
Age & 20 years & 21.80 \\
& 31 - 30 years & 69.90 \\
Study level & & 8.30 \\
& Undergraduate & 93.70 \\
Monthly income & Postgraduate & 6.30 \\
& & \\
& <R5 000 & 78.70 \\
& R5 001 - R10 000 & 11.30 \\
R10 001 - R15 000 & 2.90 \\
Source of income & R15 001 + & 7.10 \\
& Employed full-time & 6.50 \\
& Employed part-time & 5.30 \\
& Self employed & 2.70 \\
& Full-time student & 62.10 \\
& Part-time student & 12.90 \\
& Unemployed/retired & 10.50 \\
\hline
\end{tabular}

Source: Own construct

Respondents' banking profile: Table $3.1 \mathrm{a}$ and table $3.1 \mathrm{~b}$ summarize banking profile.

Table 3.1a: Bank institutions use

\begin{tabular}{lll}
\hline Bank & Count & Percentage (\%)* \\
\hline Capitec & 558 & 30.05 \\
Standard Bank & 382 & 20.57 \\
FNB & 332 & 17.88 \\
ABSA & 315 & 16.96 \\
Nedbank & 190 & 10.23 \\
Do not have a bank account & 35 & 1.89 \\
Post Bank & 19 & 1.02 \\
Other banks & 7 & 0.38 \\
African Bank & 6 & 0.32 \\
Bidvest & 5 & 0.26 \\
Mercantile & 4 & 0.22 \\
Bank of Athens & 4 & 0.22 \\
\hline Source: Own contruct
\end{tabular}

Source: Own construct $* \%$ based on total number of respondents 


\begin{tabular}{l} 
Journal of Economics and Behavioral Studies (ISSN: 2220-6140) \\
Vol. 9, No. 6, pp. 26-38, December 2017 \\
\hline \hline
\end{tabular}

Table 3.1b: Extent of channel use (1=never; $6=$ daily)

\begin{tabular}{llll}
\hline Banking channel & Mean & Std Dev. & users \% \\
\hline Bank branch & 2.82 & 1.76 & 53.30 \\
EFTPoS & 2.77 & 1.82 & 50.20 \\
Cell phone banking & 2.77 & 1.82 & 50.20 \\
Bank App & 1.78 & 1.39 & 23.30 \\
Telephone & 1.78 & 1.38 & 23.20 \\
ATM & 1.58 & 1.27 & 16.10 \\
\hline
\end{tabular}

Source: Own construct

Scale Measurement: Cronbach's alpha was used for the measuring of the reliability of the multi-item scales questionnaire (Mazzocchi, 2011; Bryman \& Cramer, 2001:71). Reliability is about accuracy, consistency and precision measurements of multiple variables (Hair et al., 2010). As a commonly used measure in quantitative research, internal consistency is used to ascertain in a set of questions, how positively items are intercorrelated. The minimum alpha setting practice standard threshold for consideration according to Field (2009:677) is 0.7. An illustration of Cronbach' alpha $(\alpha)$ sub-scales and inter-correlation aspect in relation with the present research's items is painted in Table 4 and Table 5 below.

Table 4: Cronbach's alpha $(\alpha)$ for the subscales

\section{Multi-item scale Internet banking}

\begin{tabular}{ll}
\hline Inertia & .679 \\
Technology anxiety & .769 \\
Need for Interaction & .613 \\
Previous Experience & .094 \\
Role Clarity & .764 \\
Ability & .700 \\
Extrinsic Motivation & .830 \\
Intrinsic Motivation & .882 \\
\hline
\end{tabular}

(Study sample) $<.4$ cut off

Table 5: Descriptive Statistics and Correlations

\begin{tabular}{|c|c|c|c|c|c|c|c|c|c|c|c|c|c|c|}
\hline & MEAN & SD & 1 & 2 & 3 & 4 & 5 & 6 & 7 & 8 & 9 & 10 & 11 & 12 \\
\hline IN & 3.01 & .820 & 1 & & & & & & & & & & & \\
\hline TLA & 2.69 & .874 & $351^{* *}$ & 1 & & & & & & & & & & \\
\hline NDI & 3.26 & .803 & $.234^{* *}$ & $.250^{* *}$ & 1 & & & & & & & & & \\
\hline PE & 3.04 & .786 & $.154^{* *}$ & $.150^{* *}$ & $.183^{* *}$ & 1 & & & & & & & & \\
\hline $\mathrm{RC}$ & 3.14 & .523 & $.095^{* *}$ & $.096^{* *}$ & $.204^{* *}$ & $.187^{* *}$ & 1 & & & & & & & \\
\hline $\mathrm{AB}$ & 3.23 & .626 & .051 & .033 & $.202^{* *}$ & $.201^{* *}$ & $.382^{* *}$ & 1 & & & & & & \\
\hline EM & 3.65 & .822 & -.019 & $-.019^{* *}$ & $.186^{* *}$ & $.177^{* *}$ & $.267^{* *}$ & $.407^{* *}$ & 1 & & & & & \\
\hline IM & 3.62 & .815 & .011 & $-.056^{*}$ & $.193^{* *}$ & $.196^{* *}$ & $.252^{* *}$ & $.377^{* *}$ & $.684^{* *}$ & 1 & & & & \\
\hline Gender & 1.54 & $.056^{*}$ & -.009 & $-.055^{*}$ & $-.064^{*}$ & -.023 & $.054 *$ & .039 & $.054^{*}$ & .039 & 1 & & & \\
\hline Age & 1.89 & .611 & -.040 & -.039 & -.036 & -.017 & .035 & .034 & -.029 & .015 & $-.079 * *$ & 1 & & \\
\hline Income & 1.46 & 1.123 & -.054 & $-.061^{*}$ & $-.078^{* *}$ & -.001 & .036 & .014 & -.017 & -.012 & $-.115^{* *}$ & $-.255^{* *}$ & 1 & \\
\hline Education & 4.09 & 1.350 & $-.069 * *$ & -.026 & -.002 & .037 & $.077^{* *}$ & $.074^{* *}$ & .008 & .008 & -.041 & $.315^{* *}$ & $.238^{* *}$ & 1 \\
\hline
\end{tabular}

Notes: N=1516; IN=Inertia; TLA=Technology Anxiety; NDI=Need for Interaction; PE=Previous Experience; $\mathrm{RC}=$ Role Clarity; $\mathrm{AB}=\mathrm{Ability} ; \mathrm{EM}=$ Extrinsic Motivation; IM=Intrinsic Motivation.

${ }^{*} \mathrm{p}<.05$

$* * \mathrm{p}<0.1$ (two tailed)

Construct validity: Factor analysis is a statistical multivariate method often used with three characteristics keys functions, (Stewart, 1981). The first key function consists on reducing to smaller size variables, the number in case information analysis amount is maximised. The second one is by searching in case of data being too large, qualitative and quantitative data distinction. The last key function is about hypotheses testing relative to distinction numbers or undergoing data set. Specifically, Oblimin rotation with principal 
components analysis (PCA) was used not only for determining the items factors loading, but also for the inter correlation of factors themselves (Hair et al., 2010). Proceeding with PCA involved the use of Kaiser-MeyerOlkin (KMO) for the measure of sampling adequacy (MSA) and the Sphericity Bartlett's test (Shiu, Hair, Bush \& Ortinau, 2009). The KMO index range is from 0 to 1 . Value $0.90+$ is marvellous, while value $0.60+$ is mediocre and below .50, unacceptable (Field; 2009:647). For this study, KMO index range is higher than 0.7, which is acceptable. Secondly, for proceeding with factor analysis as scientifically recommended, the statistical probability, proof of the existence of correlation matrix with significant correlations among variables, is generated by Bartlett's Test of Sphericity index $(>0.6)$, which is viewed a minimum tolerance. Lastly, in all cases the Bartlett's Test yielded p-values $(p<0.05)$, which are significant and high. Overall, more than $61.400 \%$ of the variance is explained by total of 7 items components which in combination resulted with over Kaiser's criterion 1 as Eigen values. Among items, correlations were large enough (Field, 2009:672) based on PCA indication with Barlett's test of sphericity $\mathrm{X}^{2}(1516)=15749.761, \mathrm{p}<0.001$. The index range for KMO for this analysis of 0.891 is more than 0.80 , very good value with degree of freedom (df) $=496$.For both scales (IDs and CR) loading the factor structures, are in conformity to the theory content (Previous Table 5 and Table 6 below)

Table 6: Variables KMO / Barlett's test of sphericity values

\begin{tabular}{ll}
\hline $\begin{array}{l}\text { Multi-item KMO / Barlett's test } \\
\text { (p-values) }\end{array}$ & of sphericity \\
\hline Role Clarity & $.658(.020)$ \\
Ability & $.711(.515)$ \\
Extrinsic Motivation & $.718(.000)$ \\
Intrinsic Motivation & $.878(.000)$ \\
Inertia & $.637(.004)$ \\
Technology anxiety & $.747(.000)$ \\
Need for Interaction & $.563(.800)$ \\
Previous Experience & $.485(.001)$ \\
\hline Source: Own banking
\end{tabular}

Source: Own construct; Cut off point < 0.5 (Field, 2009:660)

Table 7: PCA loadings of independent variable constructs

\begin{tabular}{lll}
\hline Independent variable & $\begin{array}{l}\text { Banking channel } \\
\text { Internet banking }\end{array}$ \\
\hline $\begin{array}{l}\text { Individual difference } \\
\left(\mathrm{X}^{2}=.972 ; \mathrm{p}=.0324\right)\end{array}$ & $\begin{array}{l}\text { Factors retained } \\
\% \text { variance }\end{array}$ & 1 \\
$\mathrm{CR}\left(\mathrm{X}^{2}=10.205 ; \mathrm{p}=\right.$ & $\begin{array}{l}\text { Factors retained } \\
\text { \% variance }\end{array}$ & $52.014 \%$ \\
$.001)$ & & $55.054 \%$ \\
\hline
\end{tabular}

Source: Own construct

Test of model and hypotheses: Between CR variables and the independents one, in relation with IB trial test, there is no effect of mediation. For instance, according to Table 5, variable ability mediating effect on trial (dependent variable) is not at all significant [coefficient =-21.169; $(p=.998)$ ]. This fact means that, by the factor ability none of the independent variable is found mediated through ability factor. In addition, among independent variables, not all items were found mediated by the remaining three mediating variables, role clarity, extrinsic motivation and intrinsic motivation respectively with coefficient and $\mathrm{p}$ value, $[\mathrm{B}=-1.661 ; \mathrm{p}=$ $.000],[\mathrm{B}=-1.551 ; \mathrm{p}=.000]$ and $[\mathrm{B}=-1.259 ; p=.000]$. Individual variables for instance anxiety, income and education are mediated by role clarity, while intrinsic motivation mediated age. None of the remaining individual variables was found mediated through any of the others factors. Overall, not all independent variables antecedent predictors with direct effect on trial, were found at least mediated by one mediating factor. As deduction for IB product there is no mediation of CR in relation with the independent variables (individual differences). 


\begin{tabular}{l} 
Journal of Economics and Behavioral Studies (ISSN: 2220-6140) \\
Vol. 9, No. 6, pp. 26-38, December 2017 \\
\hline \hline
\end{tabular}

Table 8: Results of tests of mediation: IB

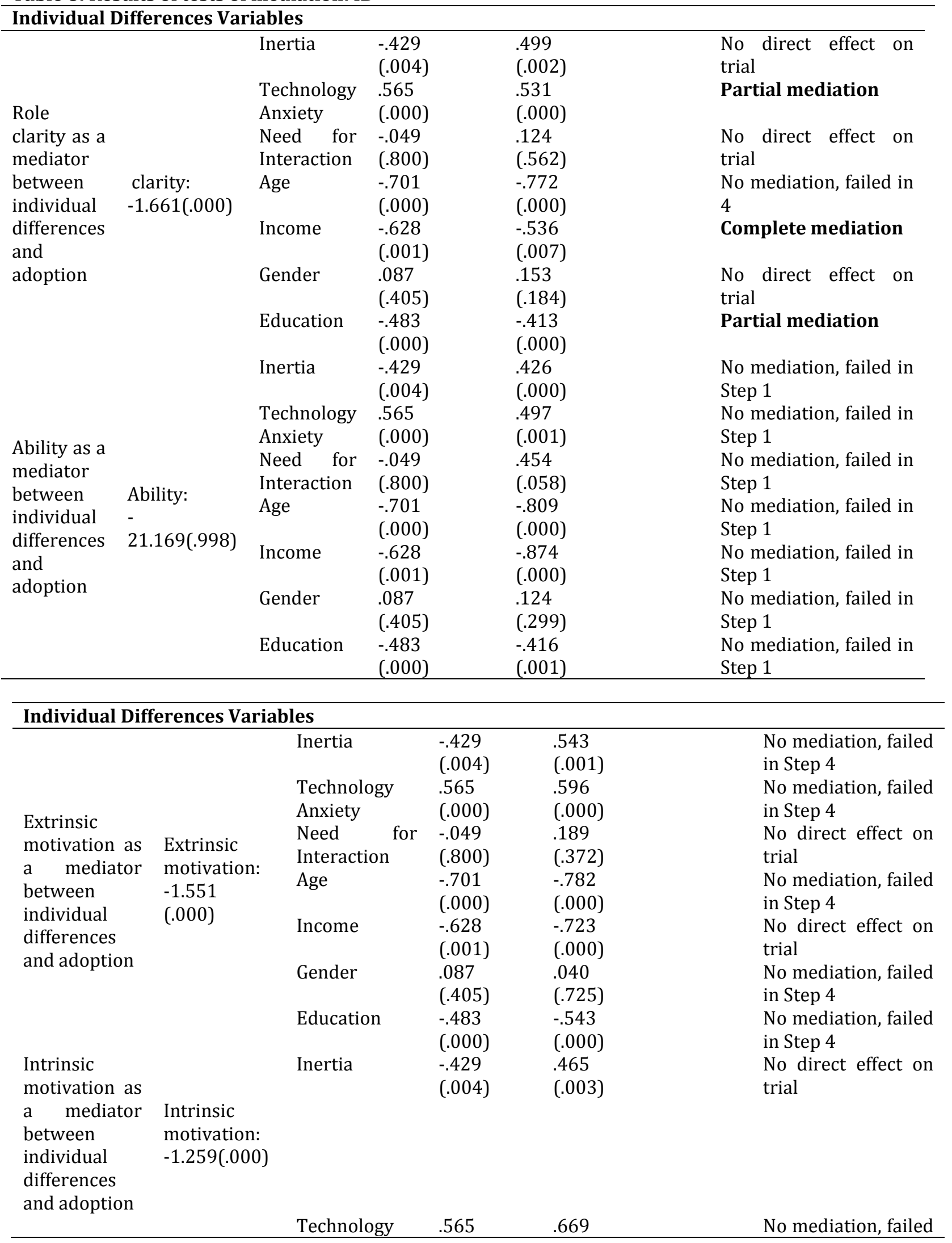




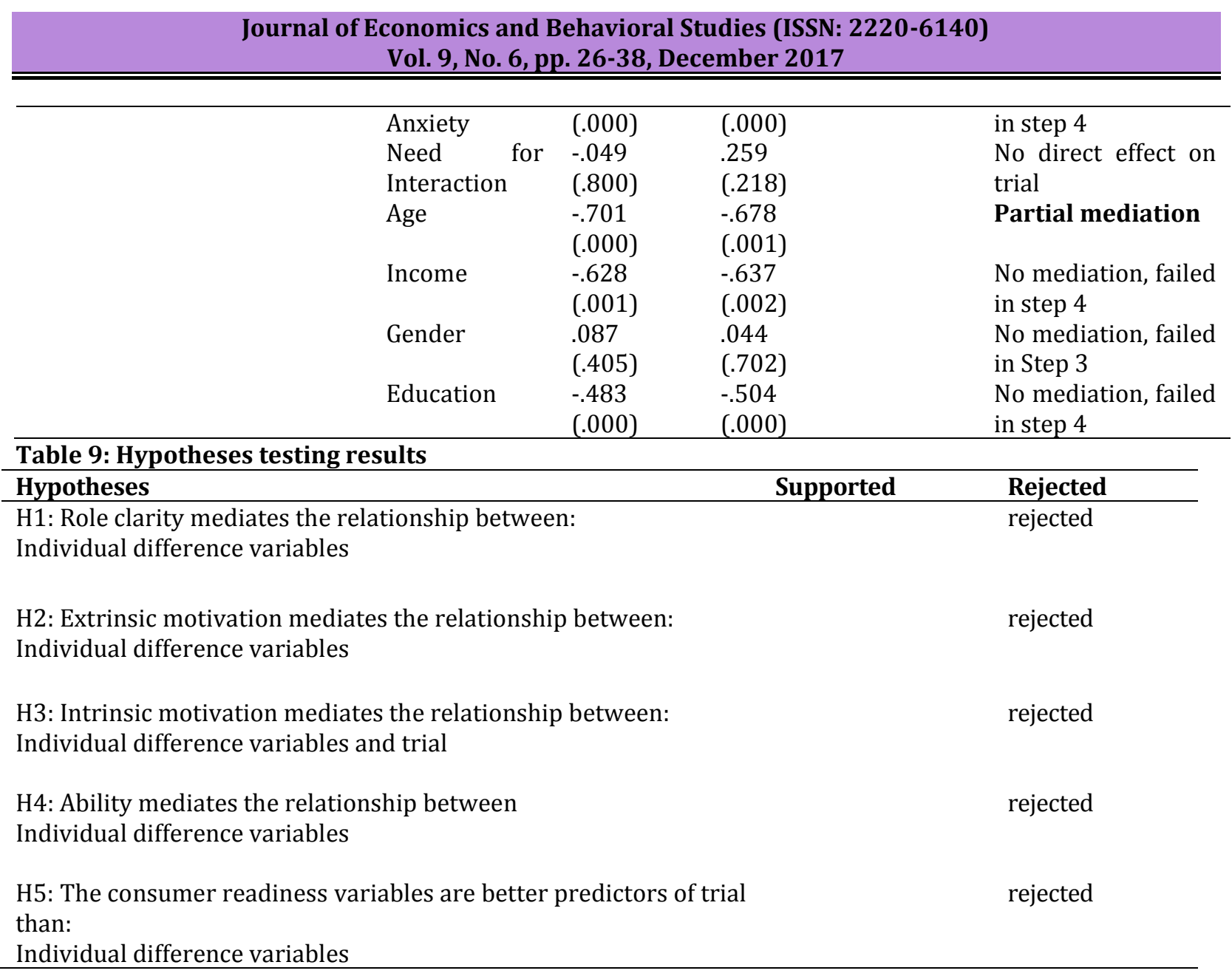

Table 10: Classification accuracy (IB present study)

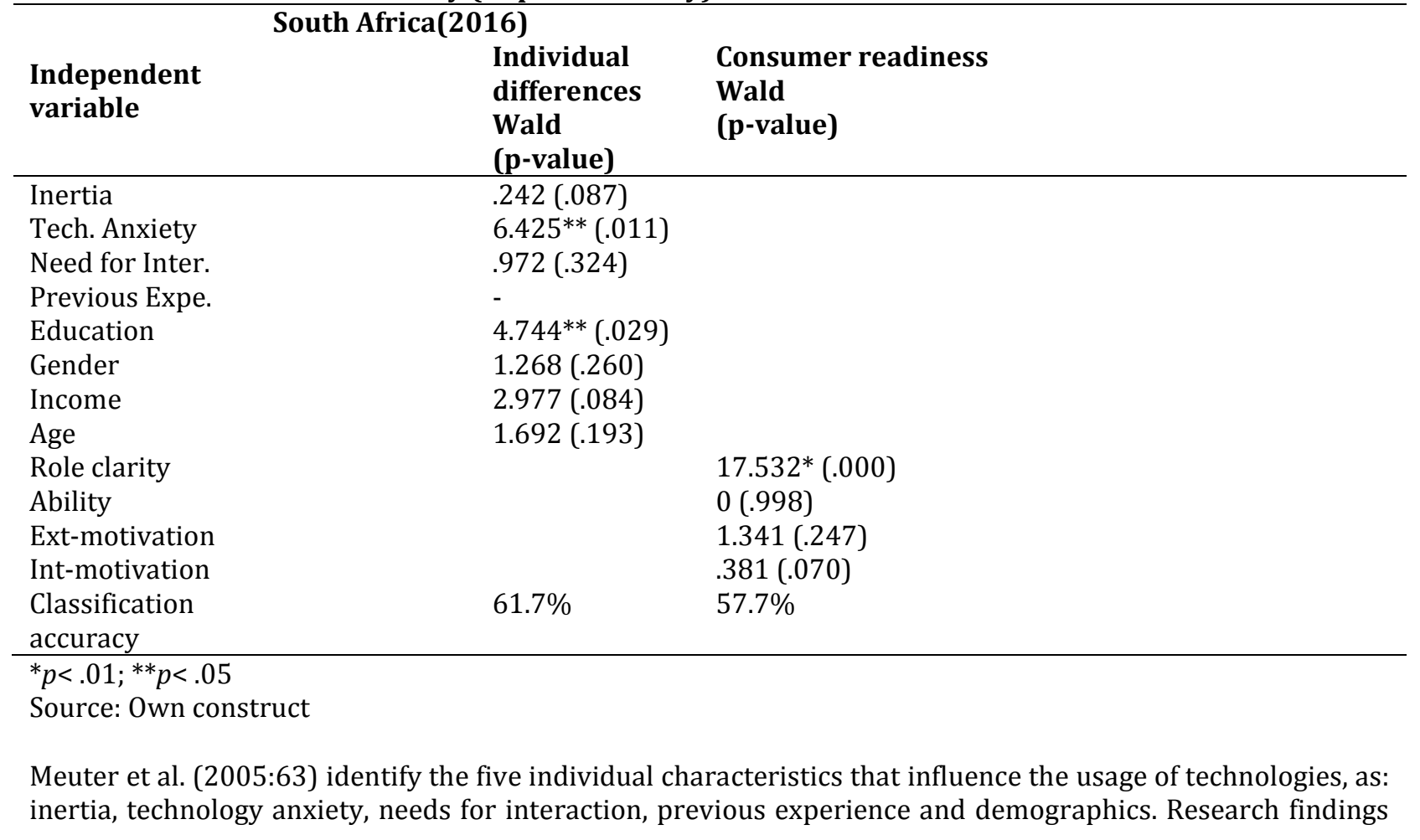


demonstrate that these factors also influence technology innovation adoption (Kelly, Lawlor \& Mulvey, 2010:1). Individual differences variables, (especially technology anxiety variable) are found with greater predictive power in comparison to consumer readiness variables regarding IB adoption in South Africa (Table 10 on classification accuracy). This result is opposite to existing one conducted by Meuter et al. (2005) regarding USA SSTs market which underlined CRwith greatest predictive power over innovation characteristics and IDs. Technology anxiety as previously described is a "modern disease of adaptation caused by an inability to cope with new computer technologies in a healthy manner" (Fiehn, 2010:255). While, role clarity refers to knowledge and understanding of customers regarding the nature of contribution needed to take place (Meuter et al., 2005). In fact customers with adaptation disease to cope with computer technology such IB, doesn't have knowledge of what to do and to expect as performance from using IB and therefore fall into computer-related fears' delusions, which is qualified as ever-present threats from information technology (Mason, Stevenson and freedman, 2014).

Discussion: By contradiction with Meuter et al. (2005) findings, this paper in South Africa, individual personality (exogenous variables) provides better explanatory power in describing adoption". Individual characteristics outperform consumer readiness predictors for classification accuracycompared to CR. Technology anxiety and education as individual differences variables, compared to role clarity; predict better IB adoption in South Africa. In other words, this paper corroborates many studies such as TRI Parasuranam (2000), Meuter et al. (2005) and also by Kellyet al. (2010), Dhurup, Surujal and Redda (2014), is not usable in South Africa country alone, but recommendable to the use for larger applicability to the body of knowledge.Encouraging and useful for both researchers and bank managers are the present survey findings, which also demonstrated that South Africa's nation-specific conditions are efficiently explainable through research work studies. Evidently, there is need of extending this work to others SSTs as far as this framework is concerned. Many empirical research's variables with adoption behaviour as determinant (Hoppe, Newman \& Mugera, 2001:1; Akinci, Aksoy \& Atilgan, 2004:212; Cai, Yang \& Cude, 2008:151; Maduku, 2013:76; Ramavhona \& Mokwena, 2016:2) based on one common grouping only and used for IB in South African context mostly. But due to findings inconsistencies' some phenomena could not be explained (Meuter et al., 2005:62). This stands as present paper's motive, for phenomena's better explanation, two sets of variables are to consider simultaneously. "To date, the question of why individual differences influence adoption behaviour has been left largely unexplored" (Meuter et al., 2005:62). Though exciting, unexplored fields are left within the present paper which is still needed to be explored. For such reason, future's research needs are real and still pending.

University student's sample was used for conducted research, homogeneous as sample (Calder, Phillips \& Tybout.1981:200). However a larger rank of consumers could have been included; this through the large sample size $(\mathrm{n}=1516)$ scales' validation therefore is viewed as limitation.The applied theory model, exclusively referred to individual differences, knowing that other theories such as TAM, TRA and TPB could also have been considered. Finally, only Gauteng Province is considered for the investigation, which is a limitation as the whole country could have been covered.In order to compare others research investigations results with this paper's one, future studies are indicated for covering other provinces. By so doing, reliable parameters affecting South Africa's IB consumer choice making and choice behaviour can be available for both bank marketers and the body of knowledge. Other SSTs as cell phone banking and ATM adoption predictors can also be interested, using Meuter et al. (2005) model, for useful tools provision to bank decision-makers and for filling also within the domain, the related research gap.

\section{Conclusion}

In South Africa, the attempt in responding to the above mentioned objective, proves first of all that all two mentioned variables, predict significantly adoption of IB. Also as second aspect from study result, the CR variable mediates between explanatory variables (individual differences) and trial. Finally, the objectively comparison of both variables' predictive power, shows that individual differences (personal individuality, exogenous variables) in South Africa were found relatively to consumer of IB regarding decision making and choice behaviour with better predicting power. 


\section{References}

Adeboye, E. A. (2015). Open Heavens. A guide to close fellowship with God.Vol. 15(2015).

Agwu, M. E. (2015). Analysis of obstacles to uptake of Internet Banking Services in Nigeria.ResearchJournal of Business and Management, 2(1), 99-114.

Akinci, S., Aksoy, S. \& Atilgan, E. (2004). Adoption of Internet banking among sophisticated consumer segments in an advanced developing country. International Journal of Bank Marketing, 22(3), 212-232.

Baliamourne, M. N. (2002). The new Economy and Developing Countries Assessing the Role of ICTDiffusion

Berndt, A. D., Saunders, S. G. \& Petzer, D. J. (2010). Readiness for banking technologies in developing countries. Southern African Business Review, 14(3), 47-76.

Black, N. J., Lockett, A., Winkhlofer, H. \& Ennew, C. (2001). The adoption of Internet Financial Services. A qualitative study. International journal of Retail \& Distribution Management, 29(8), 390-398

Brown, I., Cajee, Z., Davies, D. \& Stroebel, S. (2003). Cell phone banking; Predictor ofadoption in SA. An explanatory study. International Journal of Information Management, 23, 381-394.

Bryman, A. \& Cramer, D. (2001). Quantitative Data Analysis with SPSS release 10 for windows: A guide for Social Scientists, London: Routledge.

Cai, Y., Yang, Y. \& Cude, B. (2008). Inconsistencies in U.S consumers' attitudes toward anduse of electronic banking: an empirical investigation. Journal of leisure Research, 25(3), 263-280.

Calder, B. J., Phillips, L. W. \& Tybout, A. M. (1981). Designing Research for Application. Journal of Consumer Research, 8(2), 197-207.

Clemes, M. D., Gan, C. \& Du, J. (2012). The factors impacting on customers decision to adopt Internet banking. Bank and Banks Systems, 7(3), 33-49.

Daniel, W. W. \& Terrel, J.C. (1995). Business statistics: For management and economics. 7th ed. Boston: Houghton Mifflin.

Dhurup, M., Surujlal, J. \& Redda, E. (2014). Customer perceptions of online banking servicequality. Mediterranean Journal of Social Sciences, Rome - Italy.

Emory, C. W. \& Cooper, D. R. (1991). Business Research methods. $4^{\text {th }}$ ed. Homewood, IL: Irwin.

Falkena, H., Bamber, R., Liewellyn, L. \& Store, T. (2001). Financial Regulations in SouthAfrica; SA . Financial Sector Forum.

Fiehn, B. (2010). Stressing out: Handling change in a digital world. Community and Junior College Libraries, $16(4), 255-258$

Field, A. (2009). Discovering Statistics Using SPSS, $3^{\text {rd }}$ Edition. Thousand Oaks, CA, Sage.

Gao, P. \& Owolabi, O. (2008). Consumer adoption of Internet banking in Nigeria.International Journal of Electronic Finance, 2(3), 284-299.

Hair, J. F., Black, W. C., Babin, B. J., Anderson, R. E. \& Tatham, R. L. (1998). Multivariate data analysis. $5^{\text {th }}$ ed. Upper Saddle River, N J. Prentice Hall.

Healy, M. \& Perry, C. (2000). Comprehensive Criteria to judge Validity and Reliability ofQualitative Research within the Realism Paradigm. Qualitative MarketResearch: An International Journal, 3(3), 118-126.

Hoppe, R., Newmann, P. \& Mugera, P. (2001). Factors affecting the adoption of Internetbanking in SA. A comparative study. Department of Information Study: University of Cape Town.

Kelly, P., Lawlor, J. \& Mulvey, M. (2010). A review of key factors affecting the adoption ofSST in tourism. THRIC Conference. Shannon.

Kyobutungi, A. (2014). Internet banking and customer satisfaction of commercial banks in Uganda: A Case study of Centenary Rural Development Bank in Mbarara municipality. Http://www.academia.edu/7388611/internet_banking_and_customer_satisfaction_of_commercial_ban ks_in_a_case_of_study_centenary_rural_development__bankin_mbarara_municipality

Kuppens, P., Allens, N. B. \& Scheeber, L. (2010). Emotional inertia and psychological Maladjustment. Psychological Science Journal, 21(27), 984-991

Laukkanen, T., Sinkkonen, S., Kivijarvi, M. \& Laukkanen, P. (2007). How personal values determine consumer resistance to mobile banking. International Business Academics Consortium (IBACNET)

Maduku, D. K. (2013). Predicting retail banking customers' attitude towards Internet banking services in South Africa. Southern Africa Business Review Journal, 17(3), 76-100.

Malholtra, N. (2010). Marketing Research: An Applied Orientation, 6th Edition. UpperSaddle River, NJ Pearson.

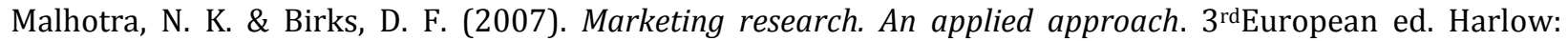
Pearson Education. 
Mallat, N. (2007). Exploring consumer adoption of mobile payments - a qualitative study.Journal of Strategic Information Systems, 16, 413-432.

Mason, O., Stevenson, C. \& Freedman, F. (2014). Ever - present threats from information Technology: The Cyber-Paranoia and Fear Scale.

Manson, H. (2002). Driving home value to banking customers. Http://www.mediatoolbox.co.za/pebble.asp?p=63\&relid=3126.

Mazzocchi, M. (2011). Statistics for Marketing and Consumer Research. London, Consumer buying behavior in financial services: an overview. InternationalJournal of Bank Marketing, 10(5), 4-12. Sage.

Meuter, M. L., Bitner, M. J., Ostrom, A. L. \& Brown, S. W. (2005). The New Service Encounter: Customer Usage and Satisfaction with Self-Service Technologies. The Journal of Marketing, 69, 61-83.

Moyo, J., Nandwa, B., Oduor, J. \& Simpasa, A. (2014). Financial Sector Reforms, Competition andBanking System Stability in Sub-Saharan Africa. Macroeconomic Challenges Facing Low-Income Countries. New Perspectives

Mungunle, C. M. \& Van Vuuren, J. J. (2016). Validating a measurement for entrepreneurship using Confirmatory Factor Analysis. ActaCommercii, 16(1), a 397- http://dx.doi.org/10.4102/ac.V16/1.397

Nel, J. (2013). Cell phone banking adoption and continuance of use in an Internet bankingcontext: A study of consumers' cross-channel cognitive evaluations. Stellenbosch University.

Onay, C. \& Ozsaz, E. (2013). The impact of Internet banking on brick and mortar branches: The case of Turkey. Journal of Financial Services Research, 44(2), 187-204. Http://dx.doi.org/s10693- 011-0124-9

Oyserman, D. \& Sorrenson, N. (2009). Understanding cultural syndrome effects on whatand how we think. A situated cognition model in R. Wyer, Y. -y. Hong. and C. -y Chiu Editions, Understanding culture. Theory, Research and Application: 25-52. NY; Psychology, press.

Pallant, J. (2010). SPSS Survival Manual: A step by step guide to data analysis using SPSS,4th Edition. Berkshire, UK, McGraw-Hill.

Parasuraman, A. (2000). Technology Readiness Index (TRI). A multiple item scale tomeasure readiness to embrace new technologies. Journal of Service Research, 2(4), 307-320.

Perry, C. (2002). A structured approach to presenting theses: notes for students and their supervisors.International Journal of Organizational Behaviour, 16(1), 1-12

Ramavhona, T. C. \& Mokwena. S. (2016). Factors Influencing Internet banking in South African rural Areas.South African journal of Information Management, 18(2), a642.htt://dx.doi.org/10.4102/sajim.V18iz-642

Rugimbana, R. (1998). Values, Perceptions, and Consumer Preference Patterns for PersonalBanking Technologies in Australia and Malaysia, MacQuarie University. PhD(Marketing).

Sathye, M. (1999). Adoption of Internet banking by Australian consumers: an empirical investigation.International Journal ofbanking Marketing, 17(7), 324-334

Seligman, L. (2006). Sensemaking throughout adoption and the innoation-decision process. European Journal of Innovation Management, 9(1), 108-120.

Shambare, R. (2012). Predicting consumer preference for Remote Banking Services in SouthAfrica and Zimbabwe: The role of consumer perspections versus, personality variables. D.Tech Thesis: Tshwane University of Technology. SA.

Shiu, E., Hair, J., Bush, R. \& Ortinau, D. (2009). Marketing Research. Berkshire, McGraw-Hill.

Szmigin, I.T.D. \& Bourne, H. (1999). Electronic cash: a qualitative assessment of its adoption. International Journal of Bank Marketing, 17(4), 192-202.

World Wide Web. www.allbankingsolutions.

$\mathrm{Wu}$, J. (2005). Factors that influence the adoption of internet banking by South Africans in the Ethekweni metropolitan region. Dissertation of Master of Technology. Marketing Department, Durban Institute of Technology.

Yiu, C. S., Grant, K. \& Edgar, N. (2007). Factors affecting the adoption of Internet banking in Hong Kong: implication for the banking sector. International Journal of Information Management, 27(5), 336-351. 